\title{
Assimilate allocation and carbon reserves in Juglans regia L. seedlings
}

\author{
A. Lacointe \\ Station de Bioclimatologie, INRA, Domaine-de-Crouelle, F-63039 Clermont-Ferrand, France
}

\section{Introduction}

This study was undertaken to answer 3 questions, some of which have been debated by several authors, e.g., Hansen (1967) and Kandiah (1979) on apple trees or Petrov and Manolov (1973) on peach trees. Can a growing organ simultaneously be active as a storage organ? Is a given storage area active at different times? Are the dynamics of reserves different between the stem part, which will bear the next year's shoot, and the rest of the stem?

\section{Materials and Methods}

\section{Plant material}

Walnuts (Juglans regia L.) were sown outdoors, on 5 June 1986, in individual pots provided with an automatic irrigation system. Germination occurred around June 20th. The stem elongation was initially quite fast until early July, building up the 'lower stem' with scaly leaves, then much slower, building up the 'upper stem' with true leaves.

\section{${ }^{14} \mathrm{C}$ feeding}

On August 1st (late primary growth; only a few short internodes were still being built: Fig. 1), 72 plants were selected for homogeneity and fed for $5 \mathrm{~h}$ with ${ }^{14} \mathrm{CO}_{2}$ using a large assimilation chamber; 24 plants at a time received a total of $18.5 \mathrm{MBq}(500 \mu \mathrm{Ci})$. Another set of 72 plants were fed on October 8th (primary growth had stopped in late August). 2-3 plants were sampled the day after feeding and $3 \mathrm{~d}$ later, then 8-9 monthly until bud-break (late May). They were divided into 5 perennial organs (Fig. 1), plus leaves when present, frozen in liquid nitrogen, freeze-dried and weighed.

The ${ }^{14} \mathrm{C}$ distribution was analyzed qualitatively by autoradiography and quantitatively with an argon-methane flow counter after dry-grinding.

\section{Results}

Autoradiographs (schematic drawings, Fig. 2)

\section{The taproot}

In both experiments, the labeling pattern was stable after 3 days and remained unchanged until bud-break. In the August experiment, unlabeled wood was produced from the cambial zone, from current assimilates in late summer. The October labeling, however, showed that wood production had stopped by that time, since no unlabeled wood was produced. The cortex 


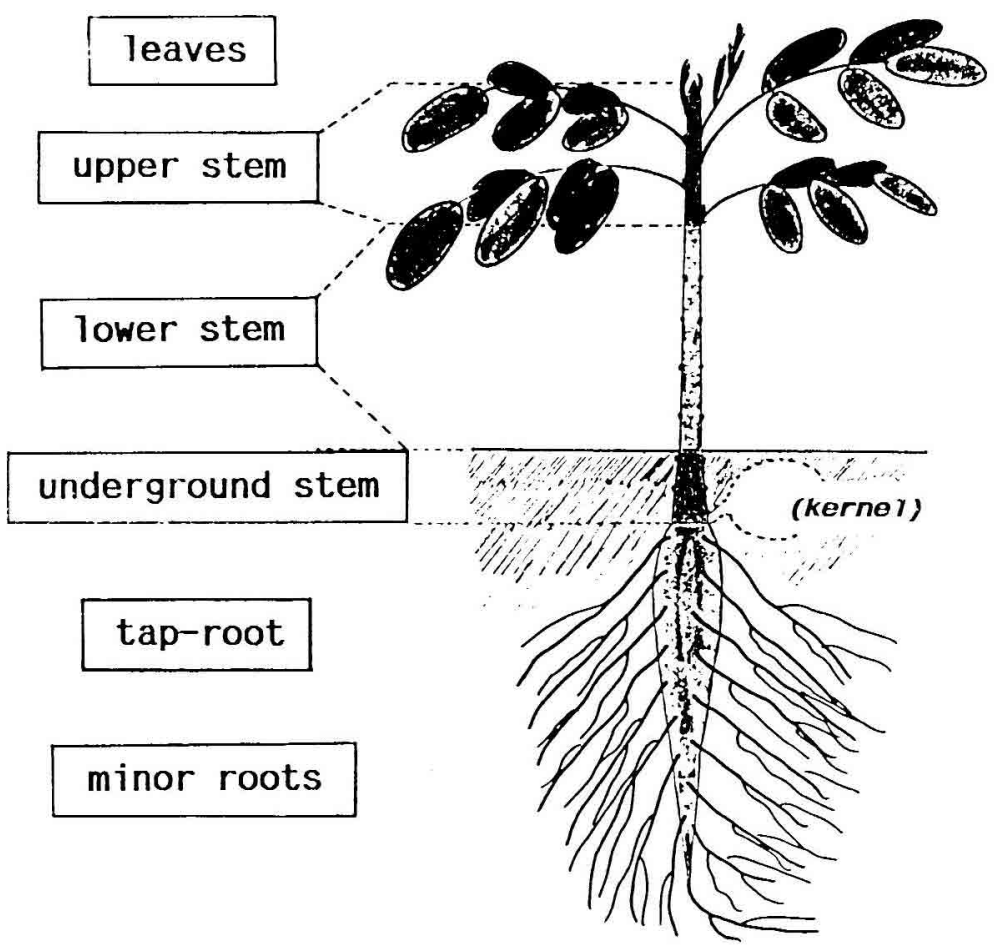

Fig. 1. Fractionation of the walnut seedling into 6 main organs.

and the central parenchyma (the predominant tissues) were rather uniformly labeled in both experiments.

\section{The upper stem}

Although it was not quite clear before early September in the August experiment because of the high amount of ${ }^{14} \mathrm{C}$, the labeling patterns seemed stable after a few days here too. They were, however, quite different between both experiments.

In August, most of the ${ }^{14} \mathrm{C}$ incorporated into the wood, whereas pith and cortex were poorly labeled. But this is true only of the lower part of the upper stem. In the apical part, the primary tissues were strongly labeled, whereas no ${ }^{14} \mathrm{C}$ could be detected in the wood (autoradiographs performed from September on): the wood was produced after ${ }^{14} \mathrm{C}$ treatment, from current unlabeled assimilates. This probably reflects the growth pattern. However, the boundary between lower and apical parts was always situated at a node: whether this 'step'-functioning of the cambium was a result of a particular pattern of primary growth or not is not clear yet.

In contrast, the distribution pattern of ${ }^{14} \mathrm{C}$ concentration after the October labeling was quite simple: none in the wood, little in the cortex, a little more in the pith and a lot in the buds and the abscission zones which were active at that time. 

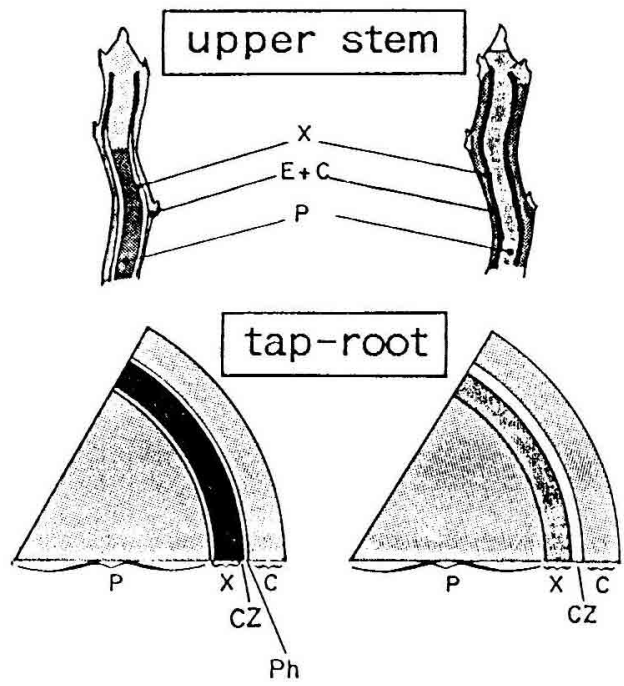

Fig. 2. Schematic drawings of autoradiographs (material collected in December). Left: August feeding; right: October feeding. CZ: cambial zone; E, C: epidermis, cortex; Ph, X: secondary phloem, xylem; P: central parenchyma (the lighter, the more labeled).

However, most of the total ${ }^{14} \mathrm{C} \quad\left({ }^{14} \mathrm{C}\right.$ concentration $x$ tissue weight) appeared to be in the pith, probably as reserves.
Quantitative allocation of ${ }^{14} \mathrm{C}$ among
organs

In both experiments, the total radioactivity recovered in the perennial parts was ca $200 \mathrm{kBq}(6 \mu \mathrm{Ci})$ per plant. The leaves retained up to fall ca $100 \mathrm{kBq}$ (August labeling) or ca $40 \mathrm{kBq}$ (October labeling).

The general pattern of distribution among organs (data not shown) was stable after $3 \mathrm{~d}$ and remained constant for the duration of the experiments. Most of the exported ${ }^{14} \mathrm{C}$ was recovered in the taproot in both experiments. However, much more ${ }^{14} \mathrm{C}$ was found in the taproot after the October labeling $(80 \%)$ than after the August labeling (55\%). This difference was also visible in the plots of the specific radioactivities (SR) (Fig. 3). Moreover, the SR of the upper stem was significantly higher than that of the lower stem in the October experiment, whereas they were similar in the August experiment.

There were, however, some slight variations with time (Aug. exp., Table 1). In autumn, the newly accumulated dry matter

Table I. Directions of variation of dry matter weights (DMW), specific radioactivities (SR) and total radioactivities (TR) of the perennial organs (August labeling).

\begin{tabular}{|c|c|c|c|c|c|c|}
\hline \multirow[t]{2}{*}{ Organ } & \multicolumn{3}{|c|}{ Autumna } & \multicolumn{3}{|c|}{ Winter } \\
\hline & $D M W$ & $S R$ & $T R$ & $D M W$ & $S R$ & $T R$ \\
\hline \multicolumn{6}{|l|}{ Stem } & \\
\hline lower & & & & y & 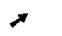 & $y$ \\
\hline underground & $\infty$ & $\downarrow$ & $\uparrow$ & $\downarrow$ & $\pi$ & $\downarrow$ \\
\hline Taproot & $\pi$ & $y$ & & $\downarrow$ & $\uparrow$ & \\
\hline Minor roots & $>$ & $y$ & & & $\uparrow$ & \\
\hline Plant & $\pi$ & $\mathbf{y}$ & & + & $\pi$ & \\
\hline Upper/lower stem & $\pi$ & $\downarrow$ & $\uparrow$ & $\pi$ & y & $\uparrow$ \\
\hline
\end{tabular}

a Autumn (leaves present): early Sept.-late Nov.

b Winter (no leaves): early Dec--mid-Mar.

Upward or downward arrows stand for increases or decreases, respectively, as determined with Spearman's coefficient of rank correlation with time over the considered season ( $\mathrm{ca} 3 \mathrm{mo}$ ).

The broader the arrow size, the more significant the increase or decrease: $\pi$ or $\vee P<0.05 ;>$ or $\downarrow<<0.10$; $\uparrow$ or $\downarrow P<0.50$. 
Specific Radioactivity $\left(\mu \mathrm{Ci} \cdot \mathrm{g}^{-1}\right)$

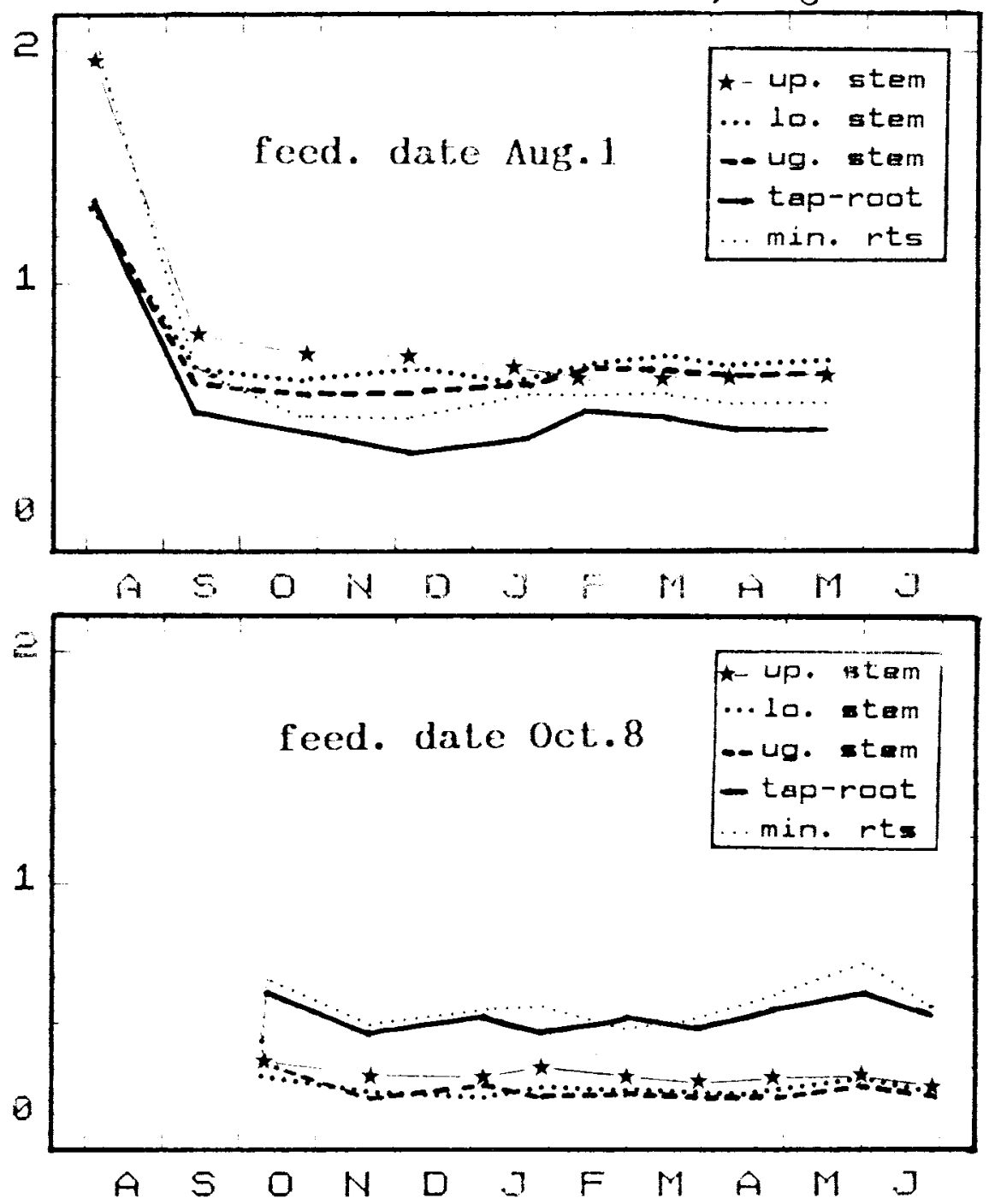

Fig. 3. Variations of the specific radioactivities of the perennial organs.

was labeled less than that already in place (compare DMW and SR). There was apparently, however, some radioactivity still circulating within the plant, since the total radioactivity of the upper stem in- creased slightly, but significantly. The upper stem was a stronger sink than the lower stem (cf. their DMW ratio). In winter, there was a slight decrease in the DMW of most organs and a correlative increase in 
SR: the disappearing DM was mostly made of unlabeled late reserves. However, as can be derived from the lower stem TR, some slightly labeled material was also lost. The lower stem was depleted faster than the upper stem.

\section{Discussion and Conclusion}

Similar to the findings of Hansen (1967) and Kandiah (1979) on apple, and of others on other species, the export of assimilates in wainut was directed more downwards in autumn than in summer. This was apparently related to the changing growth pattern of the aerial part, whereas the taproot appeared to function as a reserve-accumulating organ after either the August or October feeding, whether it was undergoing cambial growth or not. Moreover, the whole of the storage area, namely the central parenchyma, appeared to be active at all times.

In winter, the different depletion rates between the 2 parts of the stem was perhaps an indication of a transfer of reservederived nutrients from the lower to the upper part, where the preparation of budbreak probably resulted in a higher metabolic activity.

\section{References}

Hansen P. (1967) ${ }^{14} \mathrm{C}$-studies on apple trees. III. The influence of season on storage and mobilization of labelled compounds. Physiol. Plant. 20, 1103-1111

Kandiah S. (1979) Turnover of carbohydrates in relation to growth in apple trees. II. Distribution of ${ }^{14} \mathrm{C}$ assimilates labelled in autumn, spring and summer. Ann. Bot. 44, 185-195

Petrov A.A. \& Manolov P. (1973) Autumn accumulation of reserve ${ }^{14} \mathrm{C}$-labelled assimilates and their spring mobilization in young peach trees. C.R. Acad. Agric. G. Dimitrov 6, 91-102 